\title{
Management of Volunteer Activities among Elderly Persons
}

\author{
Hiroe YANAHARA \\ Department of Nursing, Faculty of Nursing \\ Shumei University \\ Chiba, Japan \\ yanahara@mailg.shumei-u.ac.jp
}

Takae MACHIDA

Departments of Nursing, Faculty of Health \& Medical Care

Saitama Medical University

Saitama, Japan

t_machi@saitama-med.ac.jp

Saori NAKAZAWA

Departments of Nursing, Faculty of Health \& Medical Care

Saitama Medical University

Saitama, Japan

sao1104ringo@yahoo.co.jp

\author{
Eiko SUZUKI \\ Department of Nursing \\ International University of Health and Welfare \\ Tokyo, Japan \\ eikosuzuki@iuhw.ac.jp \\ Maki MATSUO \\ International University \\ of Health and Welfare Graduate School \\ Tokyo, Japan \\ mk2009ny@gmail.com \\ Kyoko SATO \\ Department of Nursing, Faculty of Nursing \\ Shoin University \\ Kanagawa, Japan \\ kysato@shoin-u.ac.jp
}

\begin{abstract}
Purpose: Volunteer activities in Japan may be expected to result in a variety of effects on health conditions and social contributions of the elderly depending on the degree of their activity participation. This study aims to identify differences in the health conditions and social contributions of the elderly in relation to the degree of volunteer activity participation, and determine what effective support can be provided for these elderly persons. Further, focusing on the differences in the level of activity of the elderly persons in volunteer activities, we discuss the effect of management through SWOT analysis from the perspectives suggested by the Balanced Scorecard (BSC), which is a performance management tool. Participants and Methods: The participants are elderly persons participating in volunteer activities, living in municipal housing owned by the Kumamoto prefecture in Japan. We classified the participants into an active group who contributed to the raising of funds for activities, and a non-active group. We conducted group interviews with the volunteers, organized interview data on the thoughts of the two groups according to the five perspectives of the balanced score card (BSC) management tool: (1) learning and development, (2) participants, (3) financial matters, (4) process of conducting activities, and (5) social contributions, and conducted a Strength-Weakness-OpportunityThreat (SWOT) analysis. In the SWOT analysis internal factors are distinguished into strengths and weaknesses, and external factors into opportunities and threats. Combining the internal and external factors, problems were extracted from the perspective of a positive strategy ( $\mathrm{S}+\mathrm{O}$ : strength + opportunity), a differentiation strategy (S+T: strength $L$ threat), a stepwise strategy $(\mathrm{W}+\mathrm{O}$ : weakness + opportunity $)$, and a defensive strategy ( $W+T$ : weakness + threat). Then, we confirmed the main results by identifying the major factors in success to achieve salient aims, activity goals, and specific measures from the five perspectives provided by the BSC. Results: When comparing the
\end{abstract}

strengths of the two groups, the active group showed the following characteristics in the information collecting: more variety in the collected information (perspective of learning and development), ease of obtaining information of potential volunteers (perspective of participants), knowledge of how to raise funds (perspective of financial matters), and being physically more active and knowledgeable of the local community (perspective of social contributions).From the perspective of the process of conducting activities, both groups place importance on the relations among people. For weaknesses, and from the perspective of learning and development, the active group had difficulty in maintaining their motivation, and from the perspective of financial matters this group had difficulties in securing funds. From the perspective of social contributions, the non-active group depended on the active members. From the perspective of participants, both groups experienced a decline in physical function with age, and from the perspective of the process of activities there was a possibility that family or individual circumstances make it difficult to participate in all activities. In the SWOT analysis, combining the internal and external factors, we evaluated the directionality of volunteer activities from the five perspectives of the BSC. From the perspective of learning and development, regardless of the differences in the level of activity of the elderly persons in the volunteer activities, the volunteer members conducted a signature-collecting campaign to call for continuing volunteer activities for residents among those in their surroundings, and this made it possible to continue volunteer activities. From the perspective of the process of conducting activities, regardless of the differences in the level of activity of the elderly persons in the volunteer activities, the volunteer members became active in making remarks, and started to assume roles voluntarily. From the perspective of financial matters, the volunteer members were able to obtain donations for volunteer activities from neighboring

We declare that we have no conflicts of interest. 
establishments, as well as financial support from the social welfare council, by applying for subsidies for activities. From the perspective of participants, the number of new members increased through word of mouth spread by the existing membership. From the perspective of social cost, there was a remark that "I would like my schedule to be full of enjoyable events so that I become too busy to go to the hospital", and in fact some members did reduce the frequency of hospital visits.

Discussion: Participants in this study are members of a volunteer group of elderly persons voluntarily formed in a regional city in Kumamoto prefecture where the elderly population accounts for $25.7 \%$ and is expected to increase. It appears that there is a selfand mutual- help relationship between active and non-active members where non-active members rely on the active members who assist the non-active members to be in harmony with the volunteer activities led by the active members, and that this relationship helps maintain independent lives. For the strengths, active members were able to collect more information from the perspective of learning and development, and contributed more through physical activity from the perspective of social contributions. It can be inferred that physically more active elderly persons are in a situation where they remain able to use their cognitive functions to collect information.

For the weaknesses, the active members experienced loss of motivation. This may be due to the possibility that active members feel it a burden to assist non-active members. We wish to conduct further studies to understand how to maintain and improve motivation.

The results of the SWOT analysis from the perspectives suggested by the BSC showed that there are differences in health conditions and social contributions of the elderly depending on the participation in volunteer activities, and what types of support from health services can be expected to be effective. This study evaluated the achievements of the volunteer activity goals of elderly persons by identifying the details of volunteer activities and quantifying the goals. The elderly members began to seek for new ideas to achieve better results when they were convinced that there were favorable results of their activities. This suggests that the PDCA cycle in volunteer activities may work by effecting empowerment in the process of BSC.

Keywords; volunteer activities by the elderly persons; SWOT analysis; BSC ; management

\section{INTRODUCTION}

\section{A. Background}

In Japan, life expectancy has been extended, and in 2017 the proportion of elderly people aged 65 or older was $27.7 \%$ [1] The increase in the aged population is rapid, and those born in the baby-boom generation of 1947 to 1949 will be 75 years and above in 2025. Statistically, it has been anticipated that lifelong medical expenses will rise from the age of 75[2], and this will result in financial difficulties in providing sustainable socially secure conditions. It is necessary to ensure a financial base for pensions, medical care, welfare, and manpower to support the aging society, and to make new arrangements to deal with the developing situation.
Maslow classifies human desires into five categories: physiological desire, safety desire, belonging willingness, selfesteem, self-realization desire [3]. There are reports that the elderly themselves recognize the problem of aging society considering dementia management and lifestyle diseases themselves and also lead to the prevention of dementia and lifestyle diseases [4-6]. The existence of one's self was accepted by others, finding his own value in it satisfies the desire of self-esteem, and social doing satisfies the desire of self-realization [3]. Volunteer activities for the elderly lead to sustainable development and there is a possibility of shrinking future social systems.

The present study focuses on volunteer activities of the elderly. It has been reported that if elderly persons conduct volunteer activities for others, this will help strengthen selfreliance [7]. This is as these elderly persons will become convinced that their existence is accepted by others through the participation in volunteer activities, and their self-esteem will be satisfied by contributing to society [3], we assumed that participation in volunteer activities could contribute to decrease social costs such as medical and welfare expenses.

However, becoming involved in the volunteer activities of the elderly, we came to realize that there are many types of participation in volunteer activities, and the differences in these may have different effects on the health conditions and social contributions of these elderly persons. From this reason, we speculated that identifying and understanding differences in the level of activity of elderly persons in volunteer activities may be of help to develop effective ways to support the participation of the elderly in volunteer activities.

In the previous study, for the elderly volunteers from the viewpoint of BSC, the difference between health and social contribution by SWOT analysis was clarified [8].In this research, we focus on the difference in the aggressiveness of the elderly volunteer activities clarified in the previous research, and consider SWOT analysis and the effect of management using balanced scorecard (BSC) which is the performance management tool.

\section{B. Purpose of the study}

This study aims to identify differences in the health conditions and social contributions of the elderly in relation to the degree of volunteer activity participation, and determine what effective support can be provided for these elderly persons.

Further, focusing on the differences in the level of activity of elderly persons in volunteer activities, we discuss the effect of managing volunteer activities through a SWOT analysis from the perspectives suggested by the Balanced Scorecard (BSC), which is a performance management tool.

\section{Participants and cases studied-Characteristics of elderly volunteer activities}

a) Members of volunteer groups and activities: The participants are elderly persons who are members of a volunteer group for elderly persons and participate in the volunteer activities, living in municipal housing owned by the 
Kumamoto, prefecture, Japan. This volunteer group was established and started activities in 2002 to eliminate withdrawal from social life of elderly persons, to help group members, and to promote friendships. The group has 20 members aged 65 and older, except two who were also living in the municipal housing of the group since the construction of the buildings they reside in. All the members are living alone or are elderly couples independent of children. The main activities of the group were collecting recyclable waste in and around the residence and holding lunch meetings for the elderly not living in this municipal housing.

b) Criteria for the distinction into the active and nonactive groups: A volunteer leader and the authors determined inclusion of members who were "participating in all activities" and "contributing to the raising of funds for volunteer activities" in the active group, and others in the non-active group.

c) Relationship between purpose of the activities and administration: The volunteer leader wished the members of the group to enjoy life till the end in the familiar community by discouraging withdrawal from social life of the elderly, helping each other, and promoting friendships. The goal of the activities is to have as many people as possible participate in the volunteer activities, and share time together in mutual help through collaborative work.

\section{METHODS}

\section{A. Research method}

We employed a group interview method, the qualitative research approach proposed by Anme et al. [9-11].

\section{B. Participants}

Twenty elderly female volunteers aged between 61 and 92 , with a mean age of 74.7 years. Five were active in raising funds for activities and their mean age was 69. Fifteen were non-active with a mean age of 76.6 years.

\section{Time and place of group interviews}

Date and time: 1 hour on the activity day in December 2008

Place: Meeting room of the volunteer activity facility

\section{Process of the group interviews}

Prior to the first interview, we explained the purpose and ethical considerations of the research, including the five matters below. Participants who showed consent stayed for the interview. We explained about the necessity to record the interviews with an electronic recording device, and to transcribe the narratives. One of the authors was in charge as the moderator. The ethical considerations we explained include the following:

- Participation, withdrawal, and discontinuation of participation

- Benefits, disadvantages, and risks expected by participating in the research
- Protection of privacy and personal information

- Possibility of publication of research results

- Consultations

\section{E. Analysis}

Based on the eight perspectives of a Community as Partner model [12-14], we performed a SWOT analysis with the five perspectives of the BSC, and classified the data related to activities by the relative strengths and weaknesses. The Community as Partner model is a framework to organize information used to evaluate a community based on resident participation developed by Anderson and McFarlane, and translated into Japanese by Kanagawa et al. The BSC is a method to evaluate business management and performance proposed by Kaplan of the Harvard Business School and Norton, the president of a consulting company in 1992[15]. The SWOT (Strength - Weakness - Opportunity - Threat) analysis is a context analysis framework developed by the Harvard Business School in 1920, and reformulated by Humphrey around $1960-1970$.

In the SWOT analysis internal factors are distinguished into strengths and weaknesses, and external factors into opportunities and threats. Combining the internal and external factors, problems were extracted from the perspective of a positive strategy ( $+\mathrm{O}$ : strength + opportunity), a differentiation strategy ( $\mathrm{S}+\mathrm{T}$ : strength $\mathrm{L}$ threat), a stepwise strategy (W+O: weakness + opportunity), and a defensive strategy (W+T: weakness + threat). Then, we confirmed the main results by identifying the major factors in success to achieve salient aims, activity goals, and specific measures from the five perspectives provided by the BSC.

\section{RESULTS}

Current conditions of the volunteer group: Table 1 Internal analysis by the BSC perspective (strengths and weaknesses)

\section{A. Abbreviations and Acronyms} Strengths

(1) From the perspective of learning and development, the active members are interested in health maintenance and promotion / prevention of long-term care needs, participating in study meetings, making arrangements for lecturers, able to use the internet, being healthier, and being helpful to others. Nonactive members are able to learn and be informed at hospitals and clinics. These differences suggest that active members may be able to collect a wider variety of information.

(2) From the perspective of participants, active members are familiar with the information of elderly persons in their surroundings. Non-active members have good mutual relationships, and are not participating in nursing care services. These suggest that active members may be able to collect information about volunteer activities more easily.

(3) From the perspective of financial matters, active members have been able to obtain financial support from the social welfare council, they engage in efforts to raise funds for 
activities, obtain subsidy information, reserve meeting places for free, conduct activities in proportion to the budget available, and need no transportation expenses because they are able to participate in activities on bicycle or on foot. Non-active members do not mind collecting shopping receipts to qualify for subsidies (financial support), and have no difficulty in participating in activities because participation is free of charge. These suggest that active members may be able to collect information about raising funds.

(4) From the perspective of the process of conducting activities, active members are able to control the kind of activities, do their best for things they are able to do, operate personal computers, and consult with city council members. Non-active members try to follow the example of active members. These suggest that both active and non-active members conduct activities by placing importance on the relations among the people involved.

(5) From the perspective of social contributions, active members assist in cleaning up in and around the surroundings where they live, such as through weeding and sweeping up of fallen leaves and on a daily basis, participate in athletic meetings and summer events in the city and school districts, and host theater parties and lunches or dinners. Non-active members are able to listen to each other. These suggest that active members are physically more active and are able to collect information about their community.

\section{Weaknesses}

(1) From the perspective of learning and development, active members are limited in their ability to collect information, sometimes have difficulty in maintaining motivation when they think of non-active members participating only in lunches, and are reluctant to start new activities. Non-active members cannot make use of information due to presbyopia (poor eyesight), difficulty of hearing, and cognitive decline because of age. These suggest that active members have more difficulty in maintaining motivation and may discontinue activities depending on how they feel able to contribute.

(2) From the perspective of participants, active members cannot provide support using cars, and the mean age is advancing. Non-active members hesitate to participate in activities for free, and those of older ages living on higher floors have difficulty in participating in activities. All members receive regular outpatient treatment. These suggest that the physical functions of both groups may have deteriorated.

(3) From the perspective of financial matters, active members cannot save the money earned collecting recyclable waste as it is spent on meetings over tea, recreation, and air conditioning expenses at the meeting places. Non-active members have no room in their private budgets. These suggest that active members need effort to obtain funds.

(4) From the perspective of the process of conducting activities, there will be active members who are sometimes absent from activities due to family affairs. Non-active members are all elderly and do not have confidence in their physical strength. These show that members of both groups may sometimes be unable to participate in activities due to family and individual matters.

(5) From the perspective of social contributions, active members worry that there is no one who will/can succeed them as the volunteer leader. Non-active members think that they depend too much on the kindness of others. These suggest that non-active members are dependent on the active members.

\section{B. Table 2 Results of the management of volunteer activities}

From the perspective of learning and development, regardless of the differences in the level of activity of the elderly persons in the volunteer activities, the volunteer members conducted a signature-collecting campaign to call for continuing volunteer activities for residents among those in their surroundings, and this made it possible to continue volunteer activities. From the perspective of the process of conducting activities, regardless of the differences in the level of activity of the elderly persons in the volunteer activities, the volunteer members became active in making remarks, and started to assume roles voluntarily. From the perspective of financial matters, the volunteer members were able to obtain donations for volunteer activities from neighboring establishments, as well as financial support from the social welfare council, by applying for subsidies for activities. From the perspective of participants, the number of new members increased through word of mouth spread by the existing membership. From the perspective of social cost, there was a remark that "I would like my schedule to be full of enjoyable events so that I become too busy to go to the hospital", and in fact some members did reduce the frequency of hospital visits.

\section{DISCUSSION}

Participants in this study are members of a volunteer group of elderly persons voluntarily formed in a regional city in Kumamoto prefecture in Japan where the elderly population accounts for $25.7 \%$ and is expected to increase. The main purpose of the volunteer group is to eliminate withdrawal from social life and prevent long-term care needs. The participants are all female and the mean age of the active group was 69 years and that of the non-active group was 76.6. Compared to the ages in previous studies [16-20], the active members in this study were about three years younger, and non-active members were about two years older. The reasons that the active members in the present study were younger and the non-active members were older than in the previous studies may be because the previous studies focused on participants in activities initiated by administrative bodies to prevent longterm care needs, and limited the ages to 65 or 70 -- 80 . Further, the participants here were all female, but elsewhere it has been reported that many of the active members are male [16, 17]. We assume that this difference is derived from differences in the formation of the groups: the group here was formed voluntarily based on a community; but groups in the previous studies were formed at the initiative of administrative bodies.

For the strengths, active members were able to collect more information from the perspective of learning and development, and were more physically active from the perspective of social contributions. Seongryu suggests that differences in the amount 
of physical activity in everyday life of the elderly have a significant effect on the information processing processes in the brain [21]. Therefore, it may be inferred that the elderly persons in this study who are physically more active are in a situation where they remain able to use their cognitive functions to collect information. For the weaknesses, active members state that they have difficulty in maintaining motivation when they think of non-active members participating only in lunches.

Table 1 Internal analysis by BSC perspective (strengths and weaknesses)

\begin{tabular}{|c|c|c|c|}
\hline \multicolumn{2}{|c|}{ Strengths } & \multicolumn{2}{|c|}{ Weaknesses } \\
\hline Active members & Non-active members & Active members & Non-active members \\
\hline \multicolumn{2}{|c|}{ Perspective of learning and development } & \multicolumn{2}{|c|}{ Perspective of learning and development } \\
\hline $\begin{array}{l}\text { g: Interested in health maintenance } \\
\text { and promotion / prevention of long- } \\
\text { term care needs } \\
\text { Information: Participating in study } \\
\text { meetings } \\
\text { Information: Making arrangements } \\
\text { for lecturers } \\
\text { Information: Using internet } \\
\text { Awareness: Being healthier and } \\
\text { helpful to others } \\
\text { Participating in study meetings } \\
\text { Information } \\
\text { Making arrangements for lecturers } \\
\text { Information } \\
\text { Using internet Information } \\
\text { Being healthier and helpful to others } \\
\text { Awareness }\end{array}$ & $\begin{array}{l}\text { Information: Able to learn and } \\
\text { be informed at hospitals and } \\
\text { clinics }\end{array}$ & $\begin{array}{l}\text { Information: Limited by ability } \\
\text { to collect information } \\
\text { d: Reluctant to start new } \\
\text { activities } \\
\text { Awareness: Difficulty in } \\
\text { maintaining motivation when } \\
\text { thinking of non-active members } \\
\text { participating only in lunches }\end{array}$ & $\begin{array}{l}\text { Information: Not making use of } \\
\text { information due to presbyopia } \\
\text { (poor vision), difficulty of hearing, } \\
\text { and cognitive decline because of } \\
\text { age }\end{array}$ \\
\hline \multicolumn{2}{|l|}{ Perspective of participants } & \multicolumn{2}{|l|}{ Perspective of participants } \\
\hline $\begin{array}{l}\text { Awareness: Familiar with the } \\
\text { information of elderly persons in the } \\
\text { surroundings }\end{array}$ & $\begin{array}{l}\text { Awareness: Good mutual } \\
\text { relationships } \\
\text { g: Not participating in nursing } \\
\text { care services }\end{array}$ & $\begin{array}{l}\text { d: Not providing support using } \\
\text { cars } \\
\text { Awareness: The mean age is } \\
\text { advancing }\end{array}$ & $\begin{array}{l}\text { b: Hesitation to participate in } \\
\text { activities for free } \\
\text { d: The elderly living on higher } \\
\text { floors have difficulty in } \\
\text { participating in activities } \\
\text { g: All members receive regular } \\
\text { outpatient treatment. }\end{array}$ \\
\hline \multicolumn{2}{|l|}{ Perspective of financial matters } & \multicolumn{2}{|l|}{ Perspective of financial matters } \\
\hline $\begin{array}{l}\text { g: Obtaining financial support from } \\
\text { the social welfare council } \\
\text { b: Efforts to raise funds for } \\
\text { activities } \\
\text { Information: Obtaining subsidy } \\
\text { information } \\
\text { b: Reserving meeting places for free } \\
\text { h: Conducting activities in } \\
\text { proportion to the budget available } \\
\text { b: No transportation expenses: using } \\
\text { bicycles or walking }\end{array}$ & $\begin{array}{l}\text { Awareness: Not mind } \\
\text { collecting shopping receipts to } \\
\text { qualify for subsidies } \\
\text { b: No difficulty in participating } \\
\text { in activities because } \\
\text { participation is free of charge }\end{array}$ & $\begin{array}{l}\text { b: Unable to save the money } \\
\text { earned collecting recyclable } \\
\text { waste as spent on meetings over } \\
\text { tea, recreation, and air } \\
\text { conditioning expenses at the } \\
\text { meeting places. }\end{array}$ & $\begin{array}{l}\text { b: Having no room in private } \\
\text { budgets }\end{array}$ \\
\hline \multicolumn{2}{|c|}{ Perspective of the process of conducting activities } & \multicolumn{2}{|c|}{ Perspective of the process of activities } \\
\hline $\begin{array}{l}\text { Awareness: Able to control the kind } \\
\text { of activities } \\
\text { Awareness: Doing their best for } \\
\text { things they are able to do } \\
\text { Information: Able to operate a PC } \\
\text { c: Able to consult with city council } \\
\text { members }\end{array}$ & $\begin{array}{l}\text { d: Trying to follow active } \\
\text { members }\end{array}$ & $\begin{array}{l}\text { Awareness: Sometimes absent } \\
\text { from activities due to family } \\
\text { affairs }\end{array}$ & $\begin{array}{l}\text { Awareness: All members are aged, } \\
\text { not confident in physical strength } \\
\text { in different kinds of weather }\end{array}$ \\
\hline \multicolumn{2}{|l|}{ Perspective of social contributions } & \multicolumn{2}{|l|}{ Perspective of social contributions } \\
\hline $\begin{array}{l}\text { Awareness: Cleaning up around } \\
\text { their surroundings, weeding and } \\
\text { sweeping up of fallen leaves and on } \\
\text { a daily basis } \\
\text { h: Participating in athletic meetings } \\
\text { and summer events in the city and } \\
\text { school districts } \\
\text { h: Hosting theater and lunch parties }\end{array}$ & $\begin{array}{l}\text { Awareness: Able to listen to } \\
\text { each other }\end{array}$ & $\begin{array}{l}\text { Awareness: Worrying that there } \\
\text { is no one who will/can succeed } \\
\text { them as the volunteer leader }\end{array}$ & $\begin{array}{l}\text { Awareness: I am always dependent } \\
\text { on the active members. }\end{array}$ \\
\hline
\end{tabular}


Table 1 Internal analysis by BSC perspective (strengths and weaknesses) (continued)

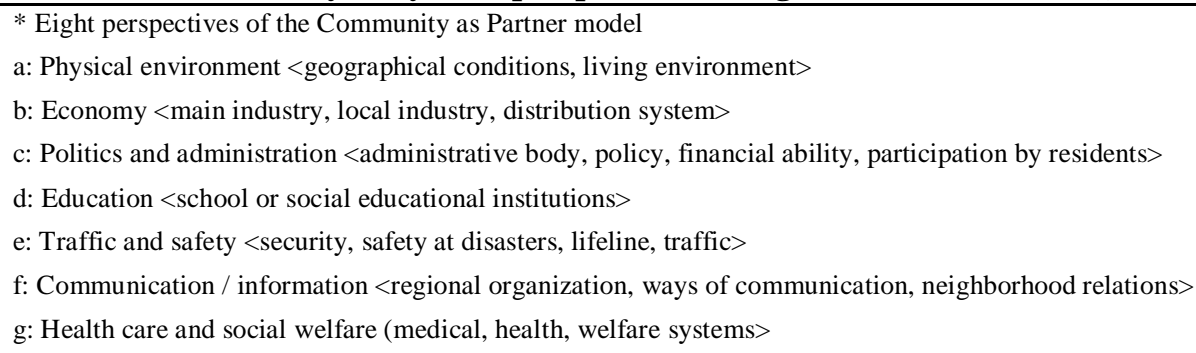

$\mathrm{h}$ : Recreation (recreation facilities, usage)

Further, as non-active members have no room in their private budgets, they appear to depend on the active members. These suggest the possibility that non-active members are a burden for the active members.

For future tasks, we need to conduct an objective evaluation on the usefulness of support for the elderly and on the changes in health conditions and social contributions before and after interventions. It is necessary to investigate other volunteer activities because there are many types of volunteer groups. Nakayama pointed out that the sharing of information and the abilities of members is linked to the cooperative relationship among members, the respect for individual members, and sharing of a sense of satisfaction in activities [22]. The findings of the present study suggest that there is a self- and mutualhelp relationship between active and non-active members where active members encourage the non-active members to participate in activities, and non-active members are trying to act in harmony with the volunteer activities led by active members, and that this relationship helps maintain independence in their lives.

As a result of the management of volunteer activities, the elderly persons recognized their own role in volunteer activities and participated in activities based on concrete plans. Hisatsune points out that organizational activities by residents present limitations which make members think that they have to follow and accede to something [23]. The management which combines SWOT analysis with the perspectives suggested the BSC in this study may have worked to encourage the elderly persons to act by themselves regardless of the differences in the level of activity of the elderly persons in volunteer activities.

Table 2 Results of the management of volunteer activities

\begin{tabular}{|c|c|c|c|c|}
\hline Perspective & Major factors of success & Activity goal & Measure & Result \\
\hline $\begin{array}{l}\text { Learning and } \\
\text { development }\end{array}$ & $\begin{array}{l}\text { Notify neighboring } \\
\text { residents of the details of } \\
\text { volunteer activities. }\end{array}$ & $\begin{array}{l}\text { Frequency of } \\
\text { reflections about } \\
\text { activities } \\
(0 \rightarrow \text { monthly })\end{array}$ & Signature-collection campaign & $\begin{array}{l}\text { Signature-collection campaign } \\
\text { made it possible to continue } \\
\text { volunteer activities. }\end{array}$ \\
\hline $\begin{array}{l}\text { Process of } \\
\text { activities }\end{array}$ & $\begin{array}{l}\text { Clearly show the roles and } \\
\text { role assignment of } \\
\text { participating elderly } \\
\text { persons. }\end{array}$ & $\begin{array}{l}\text { All members provide } \\
\text { input. }\end{array}$ & $\begin{array}{l}\text { Listen to requests about } \\
\text { volunteer activities. }\end{array}$ & $\begin{array}{l}\text { Became active in making remarks } \\
\text { and assuming roles voluntarily. }\end{array}$ \\
\hline $\begin{array}{l}\text { Financial } \\
\text { matters }\end{array}$ & $\begin{array}{l}\text { Maintain activities } \\
\text { regularly. }\end{array}$ & $\begin{array}{l}\text { Increase in available } \\
\text { funds. }\end{array}$ & $\begin{array}{l}\text { Make application for subsidies, } \\
\text { and request donations for } \\
\text { volunteer activities from } \\
\text { neighboring establishments. }\end{array}$ & $\begin{array}{l}\text { Succeeding in raising funds by } \\
\text { applying for subsidies and } \\
\text { requesting donations from } \\
\text { neighboring establishments. }\end{array}$ \\
\hline Participants & $\begin{array}{l}\text { Cooperate with Regional } \\
\text { Comprehensive Support } \\
\text { Center and neighborhood } \\
\text { association }\end{array}$ & $\begin{array}{l}\text { Issue flyers } \\
(0 \rightarrow \text { monthly }) \\
\text { Increase in the } \\
\text { volunteer participant } \\
\text { numbers. }\end{array}$ & $\begin{array}{l}\text { Report volunteer activities } \\
\text { through publicity campaign. } \\
\text { Improve the awareness of the } \\
\text { elderly participants about } \\
\text { volunteer activities. }\end{array}$ & $\begin{array}{l}\text { The number of new members } \\
\text { increased through word of mouth } \\
\text { by the members. }\end{array}$ \\
\hline Social cost & $\begin{array}{l}\text { Regardless of enthusiasm, } \\
\text { add at least one role for } \\
\text { each volunteer. }\end{array}$ & $\begin{array}{l}\text { The frequency of } \\
\text { hospital visits } \\
\text { decreased. }\end{array}$ & $\begin{array}{l}\text { Seeing someone engaged in } \\
\text { volunteer activities, showing } \\
\text { the person appreciation for the } \\
\text { effort invested, clearly enough } \\
\text { to be understood by others } \\
\text { around the person. }\end{array}$ & $\begin{array}{l}\text { There was a remark that "I would } \\
\text { like my schedule to be full of } \\
\text { enjoyable events so that I become } \\
\text { too busy to go to hospital", and in } \\
\text { fact some members reduced the } \\
\text { frequency of hospital visits. }\end{array}$ \\
\hline
\end{tabular}




\section{CONClusions}

Based on the results of the SWOT analysis from the perspectives suggested by the BSC, we found that there are differences in health conditions and social contributions of the elderly persons depending on how active the elderly here are in volunteer activities, and what types of support from health services can be expected to be effective.

This study evaluated the achievements of the volunteer activity goals of elderly persons by identifying the details of volunteer activities and quantifying the goals. The elderly members began to seek for new ideas to achieve better results when they were convinced that there were favorable results of their activities. This suggests that the PDCA cycle in volunteer activities may work by effecting empowerment in the process of BSC.

\section{ACKNOWLEDGMENT}

We wish to thank all the elderly volunteers for participating in the study.

\section{REFERENCES}

[1] Heisei 30th Edition White Paper on the Aged Society (Summary Version) Chapter 1 Situation of the Aging, p2, Cabinet Office, 2018.

[2] Health, Labour and Welfare Statistics Association, "Trends in National Health-Welfare Indicators (Kokumin eiseino doukou - Kouseino shihyou in Japanese)", Journal of Health and Welfare Statistics, Special issue, Vol. 63(9), p. 247, 2016.

[3] M. Masuda and M. Shimada, Nursing / Graficus, Health support and social security - Social welfare and social security (9) (Nursing grafica, kenkoshiento shakaihosho - shakaifukushito shakaihosho in Japanese)", Medicus Shuppan, Osaka: Publishers Co., Ltd., 2008, pp. 156-157.

[4] H.Fukuda,K.Kida,Y.Kimura, .Nishizawa,Y.Kanazawa,K.Saito,R.Mita,Y .Takusari.,"Well-Being and Depression in Residents of a Provingial City 65 Yeasold or Older", Japanese Society of Public Health, vol. 49(2),pp97-105, 2002

[5] S.Shinkai,K.Fujita,Y.Fujiwara,S.Kumagai,H.Amano,H.Yoshida,D.G.Wa ng,S.Watanabe.," Prevalence and Characteristics of Different Types of Homeboundess Among Community-Living Older Adults” . Japanese Society of Public Health, vol. 52(6),pp443-455, 2002.

[6] S.Shinkai,K.Fujita,Y.Fujiwara,S.Kumagai,H.Amano,H.Yoshida,D.G.Wa ng."Prognosis of Different Types of Homeboundness Among Community-Living Older Adults(Two-Year Prospective Study)". Japanese Society of Public Health, vol. 52(7),pp627-638, 2005.

[7] T. Anme, "Empowerment and care (Enpawamentono kea kagaku in Japanese)", Tokyo: Ishiyaku Publishers, Inc, 2007, pp. 4-12.

[8] H.Yanahara, T.Machida , M.Matsuo , S.Nakazawa , E.Suzuki.," Differences in Health Conditions and Social Contributions of Elderly Persons Depending on the Participation in Volunteer Activities". Annual Worldwide Nursing Conference(WNC2018) . doi 10.5176/2315-4330_WNC18.189 pp271-276.

[9] T. Anme, "Focus group interviews in human services II / Practical examples - Developing qualitative research based on scientific evidence (Human saabisuniokeru gurupu intabyuhou II / katsuyou jireihen kagakuteki konkyoni motozuku shitsuteki kenkyuhouno tenkai in Japanese)", Tokyo: Ishiyaku Publishers, Inc, 2003.

[10] T. Anme, "Focus group interviews in human services III / Writing a paper - Developing qualitative research based on scientific evidence (Human saabisuniokeru gurupu intabyuhou II / ronbun sakuseihen kagakuteki konkyoni motozuku shitsuteki kenkyuhouno tenkai in Japanese)", Tokyo: Ishiyaku Publishers, Inc, 2010.
[11] T. Anme, "Focus group interviews in human services - Developing qualitative research based on scientific evidence (Human saabisuniokeru gurupu intabyuhou - kagakuteki konkyoni motozuku shitsuteki kenkyuhouno tenkai in Japanese)", Tokyo: Ishiyaku Publishers, Inc, 2011.

[12] M. Miyazak, "General approaches in the latest community nursing science (Saishin chiiki kangogaku souron in Japanese)", Tokyo: Japanese Nursing Association Publishing Company, 2008, p. 132.

[13] K. Kanagawa and E. Tadaka, "Community nursing diagnosis (Chiki kango shindan in Japanese)", Tokyo: University of Tokyo Press, 2007, p. 40, \& p. 89.

[14] E. T. Anderson and J. McFarlane, translated by K. Kaneko, "Community as partner, theory and practice in nursing (Komyunithi azu patonar, chiikikangogakuno rironto jissen in Japanese)", Tokyo: Igaku-Shoin Ltd., 2008, p.148.

[15] T. Fukashiro, "III. Notes on the introduction and practice of BSC balanced scorecard to raise the evaluation of hospitals - practical guidebook for BSC promoters (III BSC dounyu, jissenno pointo byouinkachiwo takameru baransuto sukoa kardo - BSC suishinsha notameno jissen gaidobukku in Japanese)", edited by S. Takahashi, Tokyo; Medical Publications, 2007, pp. 66-78.

[16] H. Shimanuki, H. Honda, T. Ito, T. Kasai, J. Takato, Y. Sakamoto, et al., "Relationships between volunteerism and social-physical health and QOL with community-dwelling elderly participating in a long-term care prevention programme (Chiikizaitaku koureishano kaigoyobou suishin boranthia katsudouto shakai shintaiteki kenkou oyobi QOL tono kankei in Japanese)", Japanese Society of Public Health, vol. 54(11), pp. 749759, 2007.

[17] H. Honda, S. Ueki, T. Okada, S. Ebata, T. Kasai, J. Takato, et al., "Relationships between participation in community activities and psychosocial and physical health of community-dwelling elderly (Chiikizaitaku koureikanjya niokeru jishukatsudoto shinri shakaiteki kenkou oyobi saikatsu kinou tono kankei in Japanese)", Japanese Society of Public Health, vol. 57(11), pp. 968-976, 2010.

[18] S. An, H. Haga, and J. Yu, "Factors related to frequency of participation in voluntary activity of the preventive care among registered volunteers (Kaigo yobou boranthia tourokushano katsudou heno sanka hindoni kanrensuru youin in Japanese)", Journal of Gerontological Research, vol. 2, pp. 1-13, 2011

[19] H. Okamoto, "Factors and subjective effects of neighborhood association activity, volunteer activity, and help provided to friends or neighbors in community: Engagement in informal activities promotes community care among community-dwelling older persons (Koureisha boranthia katsudou oyobi yujin kinrin enjoy katsudouni kansuru youin in Japanese)", Journal of health and welfare statistics, Vol. 59(5), pp. 14-19, 2012.

[20] Y. Fujiwara, Y. Sugihara, and S. Shinkai, "Effects of volunteering on the mental and physical health of senior citizens significance of seniorvolunteering from the view point of community health and welfare (Boranthia katsudouga koureishano shinshinno eikyouni oyobosu eikyou, chiiki hoken fukushi niokeru koureisha boranthiano igi in Japanese)", Japanese Society of Public Health, vol. 52(4), pp. 293-307, 2005.

[21] Bas Seongryu, "Influence of the amount of physical activities of the elderly in everyday lives on cognitive functions and exercise performance (Nichijo seikatsuniokeru shintaikatsudou ryouno chigaiga koureisha no ninchi kinouto undou shutsuryokuni oyobosu eikyou in Japanese)", http://www.waseda.jp/sports/supoken/research/2009 2/5008A051 abs.pdf, Accessed on November 12, 2017.

[22] K. Nakayama, "Development of a qualitative evaluation index on the empowerment process of residents' organizations (Hoken senmonshoku niyoru jyumin soshikino komyunithi enpawamento kateino shitsuteki hyouka shihyouno kaihatsu in Japanese)", Japan Academy of Community Health Nursing, vol.10 (1), pp. 49-58, 2007.

[23] S. Hisatsune, "Function of leadership conducted the residents themselves (Jyumin jishinno riidaashippu kinou in Japanese)", Tokyo; Keisoushobo, 1998, p 151. 


\section{AUTHORS PROFIL}

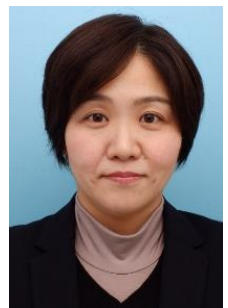

Ms. Hiroe Yanahara, obtained her Bachelor of Science in Nursing at Kurume University in 1998 and passed the Nursing and Public health nursing Licensure Examination on the same year. After working in a hospital for 9 years she worked as a public health nurse and a visiting nurse. She currently teaches Home Care Nursing at Shumei University.Japan.

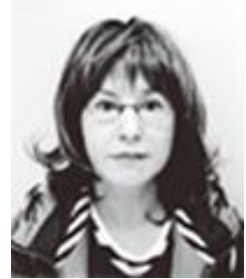

Ms. Eiko Suzuki, obtained her Phd of Science in Nursing at Tokyo Medical and Dental University. She currently professor at International University of Health and Welfare Graduate School.Japan.

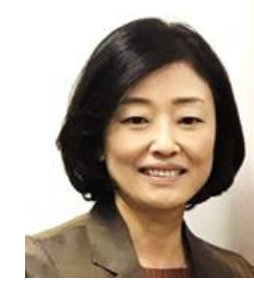

Ms. Takae Machida, master's degree of Nursing management.SAITAMA MEDICAL UNIVERSITY,Japan.

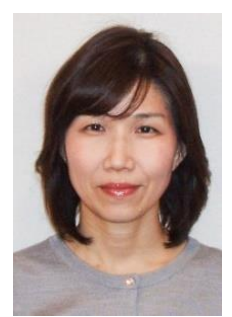

Ms. Maki Matsuo, RN,MSN, is a lecturer at Tokyo Healthcare University,Tokyo,Japan.

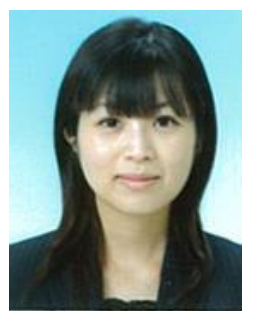

Ms. Saori Nakazawa. after working in a hospital for 13 years she worked as a I completed my master's degree at the International Medical Welfare University Graduate School. She currently teaches Fundamental Nursing at Faculty of Health \& Medical care, Saitama Medical University.Japan.

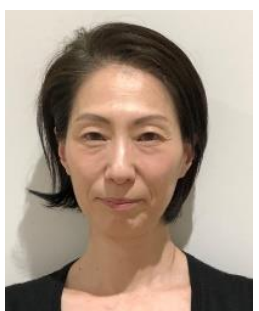

Ms. Kyoko Sato, obtained her acquired Nursing Licensure 1988. After working in a university hospital for 27 years. Certified nursing administrator. Master of Business Administration (MBA). She currently teaches Adult Nursing at Department of Nursing Shoin University.Japan. 